\title{
OPTIMASI HIDROLISIS MIKROBIOLOGI SERTA BIOAKTIVITAS ANTIBAKTERI, ANTIOKSIDAN, DAN ANTIKOAGULAN HIDROLISAT Ulva lactuca
}

\section{Optimation of Microbiological Hydrolysis and Antibacterial, Antioxidant, and Anticoagulant Bioactivity of Ulva lactuca Hydrolysate}

\author{
Ryana Tammi Putri ${ }^{\star}$, Linawati Hardjito, dan Joko Santoso \\ Departemen Teknologi Hasil Perairan, Fakultas Perikanan dan IImu Kelautan, \\ Institut Pertanian Bogor, Kampus IPB Dramaga, Jalan Agatis, Bogor, Jawa Barat, Indonesia \\ *Korespondensi Penulis: tammi.r01@gmail.com \\ Diterima: 10 Februari 2020; Direvisi: 1 Mei 2020; Disetujui: 23 Juli 2020
}

\begin{abstract}
ABSTRAK
Ulvan dalam hidrolisat Ulva lactuca merupakan senyawa bioaktif yang potensial di bidang biofarmakologi. Proses hidrolisis untuk memperoleh golongan senyawa ini dapat dilakukan secara kimiawi atau mikrobiologi. Proses mikrobiologi merupakan teknik yang potensial karena lebih mudah dan berbiaya rendah dibanding metode kimiawi. Namun, penelitian yang menggunakan teknik hidrolisis mikrobiologi masih sangat terbatas, terutama terhadap $U$. lactuca. Oleh karena itu, optimasi diperlukan agar mendapatkan teknik dengan hasil rendemen hidrolisat yang maksimal. Penelitian ini bertujuan untuk melakukan optimasi proses hidrolisis secara mikrobiologi dan menelaah aktivitas biologis ekstrak hidrolisatnya. Proses hidrolisis mikrobiologi dilakukan dengan teknik padat dan cair menggunakan kapang endofit dari tanaman Enhalus dan isolat bakteri laut dari rumput laut Eucheuma cottonii. Teknik mikrobiologis ini juga dibandingkan dengan teknik kimiawi $(\mathrm{HCl})$. Optimasi dilakukan terhadap variabel durasi waktu $(3,6,9$, dan 12 hari) hidrolisis. Hasil penelitian menunjukkan bahwa rendemen metode hidrolisis cair menggunakan bantuan kapang endofit dari tanaman Enhalus $(51,67 \%)$ dan isolat bakteri laut dari rumput laut $E$. cottonii $(52,67 \%)$, lebih tinggi dan berbeda secara signifikan $(p<0,05)$ dibandingkan teknik kimiawi $(37,02 \%)$. Waktu hidrolisis terbaik yang ditemukan adalah selama tiga hari. Sementara itu, karakterisasi bioaktivitas menunjukkan bahwa hidrolisat $U$. lactuca memiliki potensi sebagai bahan aktif antikoagulan, tanpa adanya aktivitas sebagai antioksidan $\left(\mathrm{IC}_{50}>200 \mathrm{ppm}\right)$ maupun antibakteri (menghambat 36\% Staphylococcus aureus dan Pseudomonas aeroginosa).
\end{abstract}

KATA KUNCI : antibakteri, antikoagulan, antioksidan, hirolisat, Ulva lactuca, ulvan

\begin{abstract}
The Ulvan in Ulva lactuca hydrolysate is a potential bioactive compound in the biopharmacology field. The hydrolysis process to obtain this class of compounds can be done in various ways, both chemically and microbiologically. The microbiological process is a potential technique because it is easier and cheaper than the chemical method. However, studies conducted with the microbiology hydrolysis technique are still very limited, especially for $\underline{U}$. lactuca. Thus, optimation is needed to reveal an appropriate technique that produces the maximum yield. This study aimed to optimize the microbiological hydrolysis process and identify the biological activity of the hydrolyzed extract. The microbiological hydrolysis process was performed by solid and liquid techniques using microbial endophytic fungi from Enhalus plants and marine bacteria isolated from Eucheuma cottonii. The microbiology technique was compared with chemical techniques (HCl). Optimization was also carried out on the variable of hydrolysis duration (3, 6, 9, and 12 days). The results showed that yield of liquid hydrolysis method using the microbial endophytic fungi from Enhalus plants (51.67\%) and marine bacteria isolated from E. cottonii (52.67\%), were higher and significantly different $(p<0.05)$ than that of chemical techniques $(37.02 \%)$. Moreover, the best hydrolysis duration was found in three days. Meanwhile, bioactivity testing showed that the hydrolysate was a potent anticoagulant agent, but not prospective as antioxidant $\left(I C_{50}>200\right.$ ppm) or antibacterial agent (36\% Staphylococcus aureus and Pseudomonas aeroginosa inhibition).
\end{abstract}

KEYWORDS: antibacteria, anticoagulant, antioxidant, hydrolysate, Ulva lactuca, ulvan 


\section{PENDAHULUAN}

Ulva lactuca termasuk rumput laut hijau yang umum terdapat di pesisir pantai. U. lactuca diketahui memiliki habitat di perairan laut, pantai, dan karang (Rybak, 2018). Bentuk biota ini menyerupai tumbuhan tingkat tinggi, berwarna hijau, dengan helaian daun yang tepinya memiliki bentuk gelombang. U. lactuca mengandung berbagai senyawa yang potensial di bidang biofarmakologi, salah satunya adalah ulvan. Ulvan merupakan polisakarida bersulfat dengan struktur berupa asam ulvanobioronic, yaitu bagian unit tersusun asam glukuronat dan sulfat secara berulang, serupa dengan polisakarida jenis glycoaminoglycan seperti hyaluronic acid dan chondroitin sulphate (Chiellini \& Morelli, 2011). Ulvan telah dilaporkan memiliki aktivitas antitumor, antikanker, immunomodulan, antikoagulan, antihiperlipidemik, antiinflamasi, antibakteri, dan antioksidan (Ahmed \& Ahmed, 2014; Kavitha, Subbulakshmi, Rajesh Banu, Gobi, \& Tae Yeom, 2017; Lauzon \& Serrano, 2015; Liswandari, Lantang, \& Dirgantara, 2018; Qi \& Sheng, 2015; Ramu Ganesan, Shanmugam, \& Bhat, 2018; Rizk, Aly, Matloub, \& Fouad, 2016; Synytsya et al., 2015; Yaich et al., 2017).

Proses ekstraksi ulvan secara umum dilakukan menggunakan air pada suhu $80-90^{\circ} \mathrm{C}$ selama $2-3$ jam. Rendemen hasil ekstraksi berkisar antara 8,5-15\%; tergantung prosedur ekstraksi dan purifikasi yang digunakan (Thanh et al., 2016). Ikatan antara ulvan dan protein menyebabkan metode ekstraksi dan pemurnian konvensional tidak sepenuhnya efektif dalam menghilangkan fraksi protein, bahkan setelah deproteinasi (Adrien et al., 2017). Proses hidrolisis untuk ikatan antara ulvan dan protein dapat dilakukan sebelum ekstraksi, untuk meningkatkan rendemen isolat ulvan. Hidrolisis secara umum dikerjakan dengan teknik kimia, enzim, atau mikroba. Teknik mikrobiologi merupakan metode yang lebih potensial, karena relatif mudah serta tidak membutuhkan bahan dan alat yang mahal (Khairina, Fitrial, Satrio, \& Rahmi, 2016).

Telaah mengenai hidrolisis secara mikrobiologi terhadap $U$. lactuca masih terbatas. Hidrolisis polisakarida ulvan dari Ulva sp. baru dilakukan menggunakan ekstrak enzim kasar dari bakteri Alteromonas (Coste, Malta, López, \& FernándezDíaz, 2015). Aplikasi mikroba pada proses ini masih sangat luas dan potensial mendapatkan hasil yang lebih baik, contohnya menggunakan bakteri dan kapang laut. Bakteri laut telah dilaporkan dapat melakukan proses hidrolisis karbohidrat kompleks dari rumput laut (Imran, Poduval, \& Ghadi 2016; Santhi, Bhagat, Saranya, Govindarajan, \& Jabekumar, 2014). Selain itu, kapang laut juga memiliki aktivitas selulolitik yang dapat memecah selulosa pada dinding sel rumput laut (Andhikawati, Oktavia, Ibrahim, \& Tarman, 2014). Namun, informasi mengenai optimasi yang dibutuhkan pada perlakuan mikrobiologi masih sangat terbatas.

Oleh karena itu, penelitian ini bertujuan untuk melakukan optimasi proses hidrolisis secara mikrobiologi terhadap U. lactuca dan mengidentifikasi aktivitas biologis ekstrak hidrolisatnya. Proses hidrolisis mikrobiologi dilakukan dengan teknik padat dan cair menggunakan kapang endofit dari tanaman Enhalus dan isolat bakteri laut dari rumput laut $E$. cottonii. Teknik mikrobiologi ini selanjutnya dibandingkan dengan cara kimiawi $(\mathrm{HCl})$ untuk mengetahui efisiensi hasilnya. Optimasi diharapkan dapat menghasilkan metode dan waktu hidrolisis terbaik, dengan rendemen ulvan yang tinggi serta karakteristik bioaktivitasnya.

\section{BAHAN DAN METODE}

\section{Bahan}

Bahan utama adalah rumput laut hijau kering $U$. lactuca yang berasal dari Cipatujah, Tasikmalaya, Jawa Barat. Bahan-bahan lainnya adalah akuades, isopropil alkohol (IPA) teknis, dan $\mathrm{Na}_{2} \mathrm{CO}_{3}$ teknis. Mikroba yang digunakan untuk proses hidrolisis adalah kapang EN yang merupakan kapang endofit dari tanaman Enhalus (koleksi isolat Kustiariyah Tarman, Institut Pertanian Bogor) dan isolat bakteri $\mathrm{BL}$ dari rumput laut $E$. cottonii (koleksi isolat Linawati Hardjito, Institut Pertanian Bogor).

\section{Metode}

\section{Optimasi Hidrolisis dan Ekstraksi Hidrolisat $U$. lactuca}

Hidrolisis secara mikrobiologi (padat dan cair) mengacu pada penelitian Ambarsari et al. (2018) dengan modifikasi penggunaan bakteri laut, suhu, dan waktu. Sementara itu, proses hidrolisis pembanding secara kimiawi dilakukan dengan modifikasi terhadap metode Robic, Rondeau-Mouro, Sassi, Lerat, dan Lahaye (2009). Hidrolisis padat dimulai dengan menimbang $50 \mathrm{~g}$ serbuk $U$. lactuca, kemudian disterilkan selama 15 menit, lalu ditambahkan dengan inokulum kapang EN atau bakteri BL sebanyak 10\% $(5 \mathrm{~g})$. Hidrolisat cair dilakukan dengan cara $5 \mathrm{~g}$ serbuk $U$. lactuca disterilisasi selama 15 menit, kemudian ditambahkan akuades sebanyak $100 \mathrm{~mL}$. Kapang EN dan bakteri $B L$ diinokulasi ke dalam sampel sebanyak $10 \%$ (10 mL). Sementara itu, hidrolisis secara kimiawi dilakukan menggunakan $\mathrm{HCl} 1 \%$ terhadap serbuk $U$. lactuca steril selama 9 hari. Optimasi durasi waktu hidrolisis mikrobiologi dilakukan pada variasi $0,3,6$, 9, dan 12 hari. Ekstraksi ulvan dari hidrolisat didasari 
oleh metode Lahaye dan Robic (2007). Ekstraksi dilakukan dengan pemanasan hidrolisat yang ditambahkan larutan $\mathrm{Na}_{2} \mathrm{CO}_{3} 5 \%$ pada suhu $80^{\circ} \mathrm{C}$ selama 1 jam dalam wadah stainless steel. Rendemen ekstrak hidrolisat (crude ulvan) terhadap berat kering rumput laut awal, viskositas, dan uji kelarutan, yang didasari metode Pudiastuti et al. (2013) dan Sandria, Uju, dan Suptijah (2017), menjadi parameter dalam optimasi metode hidrolisis.

\section{Karakteristik Bioaktivitas Hidrolisat $U$. lactuca}

Pengujian bioaktivitas (antioksidan, antibakteri, dan antikoagulan) dilakukan terhadap sampel yang memiliki hasil terbaik pada proses hidrolisis dan ekstraksi. Uji antibakteri dilakukan dengan metode Novianti, Aini, Putri, \& Kusumaningsih (2015), terhadap bakteri Staphylococcus aureus (gram positif) dan Pseudomonas aeroginosa (gram negatif), menggunakan kontrol positif natrium benzoat $(1,2$, 3,4 , dan $5 \mathrm{mg} / \mathrm{mL}$ ). Aktivitas diukur dengan persentase hambatan selama 24 jam pada nilai Optical Density (OD) dari panjang gelombang $600 \mathrm{~nm}$ di spektrofotometer UV-Vis (RS UV-2500). Sementara itu, pengujian antioksidan dilakukan dengan metode DPPH/2,2-diphenyl-1-picrylhydrazyl dari Lee et al. (2016) pada konsentrasi sampel 50, 100, 150, dan 200 ppm, menggunakan kontrol positif asam askobat. Pengujian ini juga dilakukan di spektrofotometer UVVis (RS UV-2500). Nilai $I_{50}$ antioksidan dihitung berdasarkan besarnya konsentrasi larutan sampel yang dibutuhkan untuk mereduksi radikal bebas DPPH sebesar $50 \%$. Sementara itu, uji antikoagulan dilakukan dengan metode Armiyanti, Paransa, dan Gerung (2013). Uji ini menggunakan $5 \mathrm{~mL}$ darah dari
4 orang relawan, dengan mengamati waktu koagulasi darah dan tingkat kekentalan darah.

\section{Analisis data}

Analisis data dilakukan menggunakan analisis ragam (ANOVA) dan uji lanjut Duncan, dengan tingkat kepercayaan $95 \%$. Keseluruhan pengujian statistik menggunakan perangkat lunak SPSS ver 16.

\section{HASIL DAN PEMBAHASAN}

\section{Hidrolisis dan Ekstraksi U. lactuca}

Rata-rata nilai rendemen tertinggi dimiliki oleh ekstrak yang dihidrolisis menggunakan metode hidrolisis cair dengan bantuan bakteri BL; yaitu sebesar $52,67 \%$ berat kering (bk) (Gambar 1). Hasil analisis ragam menunjukkan bahwa metode hidrolisis berpengaruh nyata terhadap nilai rendemen ekstrak $(p<0,05)$. Hidrolisis cair menggunakan bakteri $\mathrm{BL}$ dan kapang EN memiliki nilai tertinggi dan berbeda nyata dari perlakuan lain $(p<0,05)$.

Rendemen tertinggi penelitian ini menunjukkan hasil selaras dengan penelitian yang menggunakan metode praperlakuan berbeda. Kammoun et al. (2017) memperoleh rendemen sebesar $47,3 \%$ dari ekstraksi polisakarida U. lactuca dengan praperlakuan etanol $95 \%$ pada suhu ruang yang selanjutnya diesktraksi menggunakan air deionisasi selama 4 jam pada suhu $90^{\circ} \mathrm{C}$. Sementara itu, Postma et al. (2018) mendapatkan rendemen ekstrak polisakarida sebesar $51 \%$ bk dengan metode ekstraksi homogenisasi gesek tinggi (high shear homogenization). Perbedaan penelitian ini dibandingkan kedua penelitian tersebut adalah efisiensi energi pada

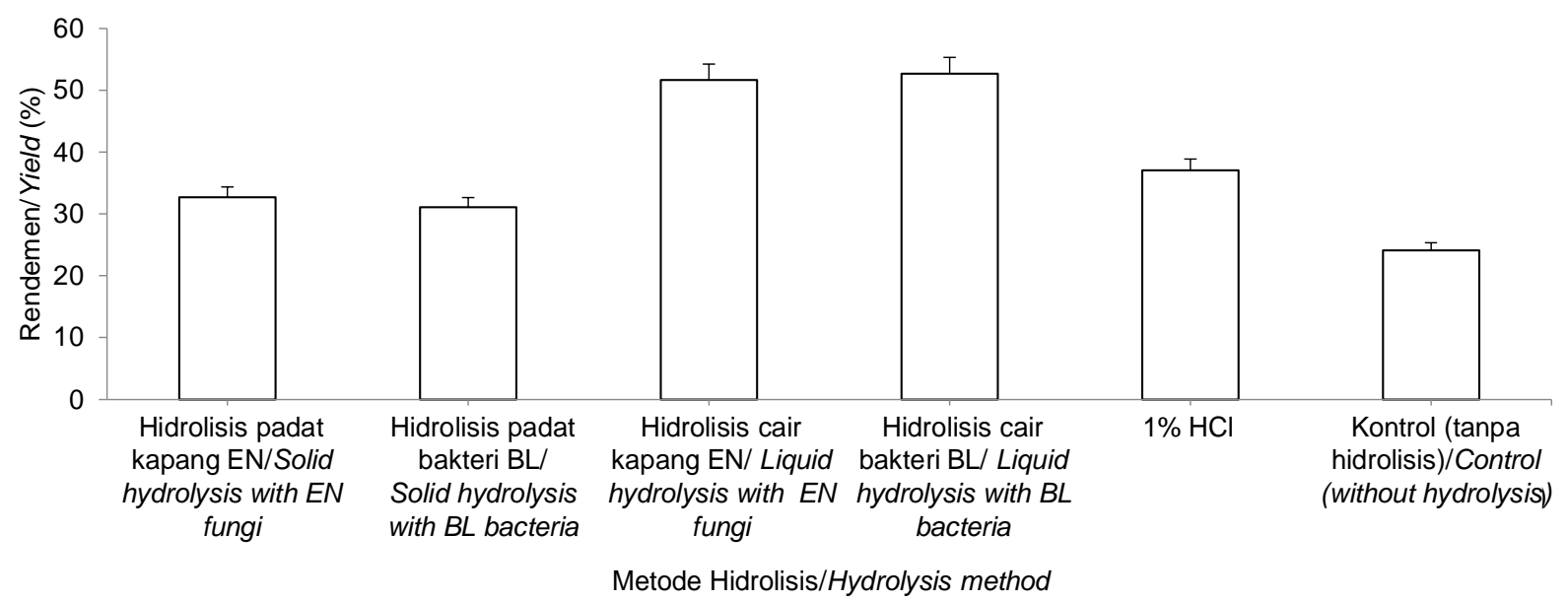

Gambar 1. Rendemen ekstrak hidrolisat U. lactuca lactuca

Figure 1. U. lactuca extract hydrolysate yield 


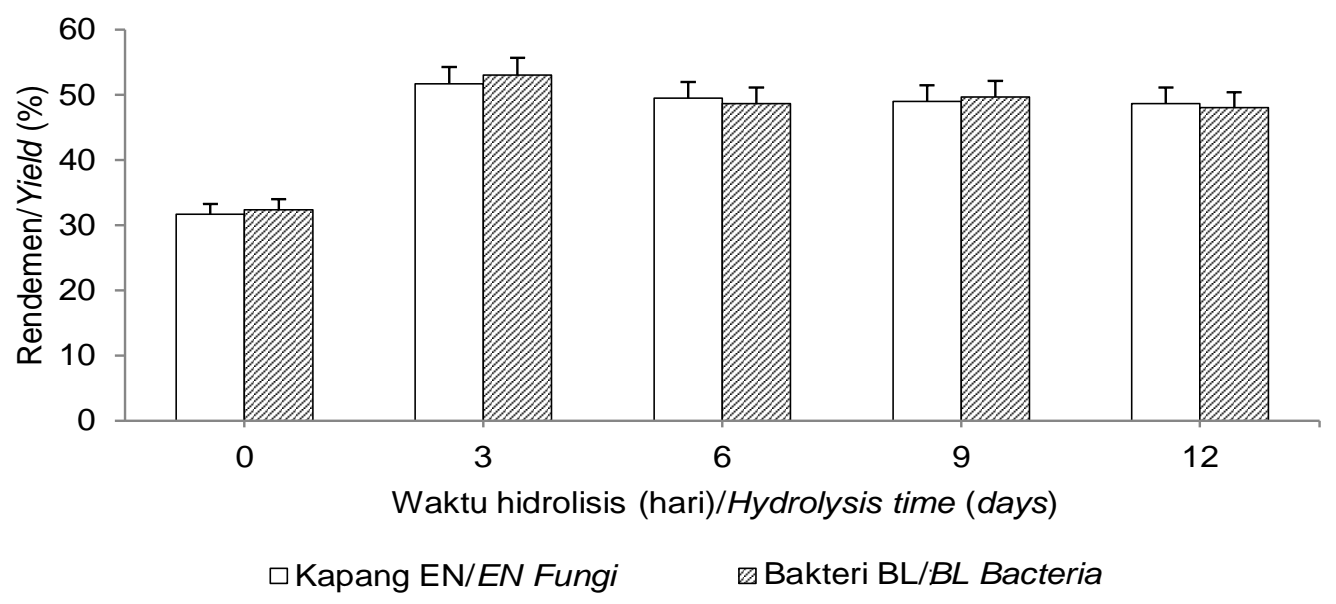

Gambar 2. Rendemen ekstrak hidrolisat $U$. lactuca dari metode hidrolisis cair menggunakan kapang endofit dari tanaman Enhalus (EN) dan isolat bakteri (BL) dari rumput laut E. cottonii, pada variasi waktu hidrolisis $(0,3,6,9$, dan 12 hari)

Figure 2. Yield of $\underline{U}$ lactuca hydrolysate extract from liquid hydrolysis methods by microbial endophytic fungi from Enhalus plants (EN) and marine bacteria isolated from E. cottonii (BL), at varied hydrolysis duration $(0,3,6,9$, and 12 days)

waktu ekstraksi yang lebih pendek (1 jam) dengan suhu $80^{\circ} \mathrm{C}$ dalam wadah stainless steel. Namun, kelemahannya adalah waktu hidrolisis yang lama (9 hari).

Tahap kedua adalah penentuan waktu hidrolisis terbaik berdasarkan rendemen dan viskositas ekstrak hidrolisat yang diperoleh. Aplikasi hidrolisis cair menggunakan kapang EN dan bakteri BL menjadi fokus dalam tahap ini, sebagai metode yang ditemukan terbaik. Rata-rata nilai rendemen tertinggi dimiliki oleh ekstrak yang dihidrolisis menggunakan bakteri BL pada hari ketiga (Gambar 2). Hasil analisis ragam menunjukkan bahwa waktu hidrolisis berpengaruh nyata terhadap nilai rendemen ekstrak hidrolisat $U$. lactuca $(p<0,05)$. Faktor metode hidrolisis dan interaksi antar faktor menunjukkan nilai yang tidak berbeda nyata $(p>0,05)$. Hidrolisis selama 3 hari menghasilkan rendemen yang paling tinggi (51,67\% untuk kapang EN dan 53\% untuk bakteri BL). Ekstrak hidrolisat, yang terdiri dari polisakarida yang larut air dan enzim selulase, akan mengurai polimer yang lebih kompleks sebagai nutrisi pertumbuhannya. Selulosa pada U. lactuca akan terhidrolisis menjadi polisakarida yang larut air (Kuhad, Gupta, \& Singh, 2011).

Sementara itu, rata-rata nilai viskositas terendah juga dimiliki oleh ekstrak yang terhidrolisis pada hari ke-3; yaitu sebesar 6,60 cP untuk kapang EN dan $6,84 \mathrm{cP}$ untuk bakteri BL (Gambar 3). Hasil analisis ragam menunjukkan waktu hidrolisis berpengaruh nyata terhadap viskositas ekstrak hidrolisat $U$. lactuca $(p<0,05)$. Faktor metode hidrolisis dan interaksi antar faktor sebaliknya menunjukkan nilai yang tidak berbeda nyata $(p>0,05)$.

Tingginya nilai viskositas ekstrak hidrolisat $U$. lactuca pada hari ke- 0 , dibandingkan dengan hari ke-3, 6, 9, dan ke 12, menandakan bahwa sampel dalam bentuk senyawa kompleks telah mengalami pemecahan secara mikrobiologis menjadi senyawa yang lebih sederhana. Sandria et al. (2017) melaporkan bahwa viskositas berhubungan dengan tingkat kelarutan suatu bahan. Pada nilai viskositas semakin rendah, kelarutan akan meningkat dan bobot molekul menjadi lebih kecil. Kelarutan suatu bahan juga bergantung pada tingkat kepolarannya. Ekstrak hidrolisat mengandung ulvan yang memiliki gugus-OH dan bersifat polar, sehingga dapat larut dalam air (Dominguez \& Loret, 2019). Hal ini menjelaskan peningkatan kelarutan sampel $U$. lactuca sesudah proses hidrolisis (Gambar 4). Berdasarkan optimasi di tahap 2 ini, maka proses selama 3 hari merupakan durasi waktu hidrolisis terbaik.

\section{Karakteristik Bioaktivitas Hidrolisat U. lactuca}

\section{Aktivitas antioksidan}

Aktivitas antioksidan ekstrak dari $U$. lactuca yang telah dihidrolisis terdeteksi lebih rendah daripada ekstrak U. lactuca tanpa hidrolisis (Tabel 1). Hasil ini memiliki kesamaan dengan penelitian sebelumnya, yaitu hidrolisat polisakarida fukoidan. Sinurat dan Maulida (2018) melaporkan bahwa fukoidan yang diperoleh melalui metode hidrolisis memiliki aktivitas 


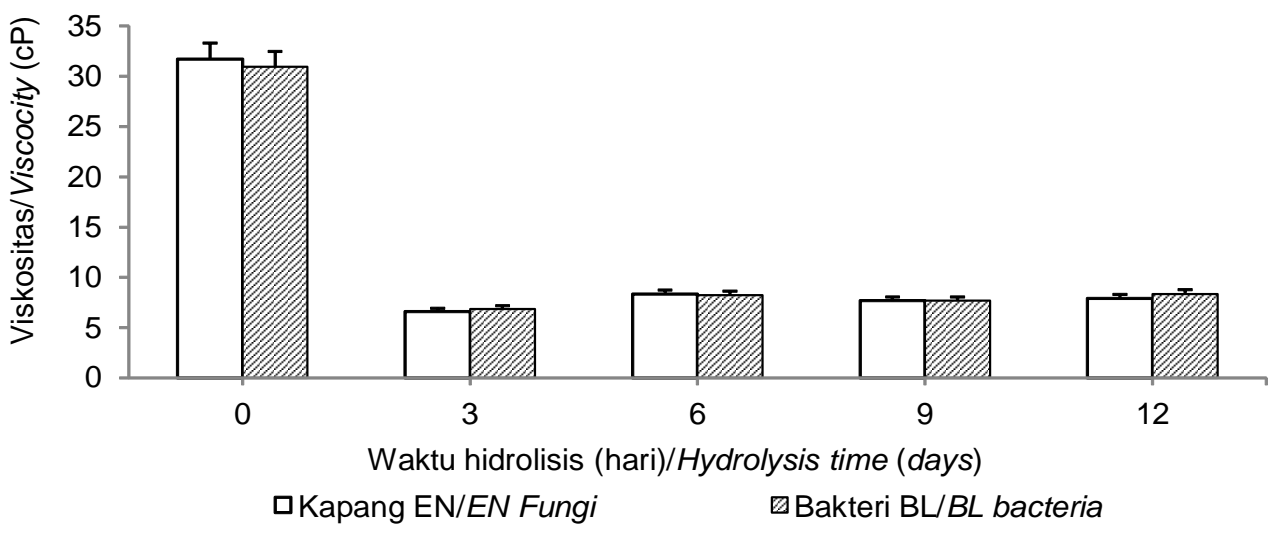

Gambar 3. Viskositas ekstrak hidrolisat $U$. lactuca dari metode hidrolisis cair menggunakan kapang endofit dari tanaman Enhalus (EN) dan isolat bakteri $(\mathrm{BL})$ dari rumput laut $E$. cottonii, pada variasi waktu hidrolisis $(0,3,6,9$, dan 12 hari)

Figure 3. Viscosity of U. lactuca hydrolysate extract from liquid hydrolysis methods by microbial endophytic fungi from enhalus plants (EN) and marine bacteria isolated from $\underline{E}$. cottonii (BL), at varied hydrolysis duration $(0,3,6,9$, and 12 days)

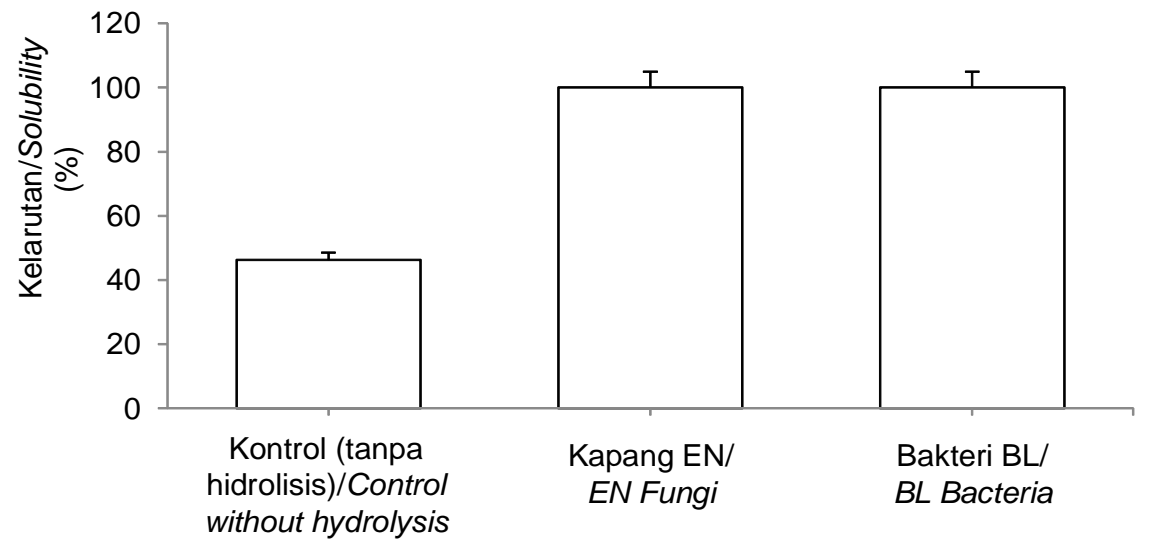

Metode Hidrolisis/Hydrolysis method

Gambar 4 Kelarutan ekstrak hidrolisis U. lactuca dengan kapang endofit dari tanaman Enhalus (EN) dan isolat bakteri $(\mathrm{BL})$ dari rumput laut $E$. cottonii

Figure 4 Solubility of extract from U. lactuca hydrolysed with microbial endophytic fungi from Enhalus plants (EN) and marine bacteria isolated from E. cottonii (BL)

antioksidan lebih rendah dibandingkan dengan crude fukoidan. Walaupun demikian, daya antioksidan penelitian ini masih lebih tinggi dibandingkan penelitian yang menggunakan bakteri asam laktat (BAL). Aktivitas antioksidan (metode DPPH) ekstrak $U$. lactuca $\left(\mathrm{IC}_{50}\right)$ yang dihasilkan oleh inkubasi $\mathrm{BAL}$ selama 36 jam adalah 1375,11 ppm (Ambarsari et al., 2018). Aktivitas antioksidan ekstrak U. lactuca dengan bahan kimia lebih tinggi dibandingkan enzimatis. Yaich et al. (2017) melaporkan IC $_{50}$ antioksidan (metode DPPH) ekstrak U. lactuca sebesar 17,88 ppm pada ekstraksi dengan $\mathrm{pH} 1,5$ serta suhu $90^{\circ} \mathrm{C}$; serta $67,38 \mathrm{ppm}$ untuk ekstraksi menggunakan enzim selulase dan protease. Kategori antioksidan adalah sangat kuat jika $\mathrm{IC}_{50}$ kurang dari 50 ppm, kuat 50-100 ppm, sedang 100-150 ppm, dan lemah 150-200 ppm (Arbi, Maruf, \& Romadhon, 2016). Berdasarkan hal ini, maka antioksidan yang ditemukan dalam penelitian ini termasuk sangat lemah.

Aktivitas antioksidan adalah kemampuan dalam menangkap spesies oksigen reaktif (ROS) atau radikal bebas dan/atau kapabilitas dalam proses pengkelatan logam (Fajardo, García-Galvan, Barranco, Galvan, \& Batlle, 2016). Aktivitas antioksidan sampel tanpa hidrolisis yang lebih tinggi dibandingkan sampel 
Tabel 1. Aktivitas antioksidan ekstrak hidrolisis U. lactuca dengan kapang endofit dari tanaman Enhalus (EN) dan isolat bakteri (BL) dari rumput laut E. cottonii

Table 1. Antioxidant activities of extract from U. lactuca hydrolysed by microbial endophytic fungi from Enhalus plants (EN) and marine bacteria isolated from E. cottonii (BL)

\begin{tabular}{|c|c|c|c|}
\hline Sampel/Sample & $\begin{array}{c}\text { Konsentrasi/ } \\
\text { Concentration (ppm) }\end{array}$ & $\begin{array}{c}\text { Inhibisi/ } \\
\text { Inhibition (\%) }\end{array}$ & $\mathrm{IC}_{50}(\mathrm{ppm})$ \\
\hline & 50 & 2.30 & \multirow{4}{*}{402.40} \\
\hline Kontrol (tanpa hidrolisis)/ & 100 & 11.62 & \\
\hline \multirow[t]{2}{*}{ Control (without hydrolysis) } & 150 & 16.78 & \\
\hline & 200 & 22.62 & \\
\hline \multirow{4}{*}{$\begin{array}{l}\text { Ekstrak hidrolisat } U \text {. lactuca dengan } \\
\text { kapang EN/Hydrolysate extract of } \\
\underline{U .} \text { lactuca with EN fungi }\end{array}$} & 50 & 6.54 & \multirow{4}{*}{750.08} \\
\hline & 100 & 10.02 & \\
\hline & 150 & 14.32 & \\
\hline & 200 & 15.36 & \\
\hline \multirow{4}{*}{$\begin{array}{l}\text { Ekstrak hidrolisat } U \text {. lactuca dengan } \\
\text { bakteri BL/Hydrolysate extract of } \underline{U} \text {. } \\
\text { lactuca with BL bacteria }\end{array}$} & 50 & 9.66 & \multirow{4}{*}{587.73} \\
\hline & 100 & 14.03 & \\
\hline & 150 & 18.10 & \\
\hline & 200 & 20.68 & \\
\hline \multirow{5}{*}{ Asam askorbat/Ascorbic acid } & 1 & 1.40 & \multirow{5}{*}{6.17} \\
\hline & 3 & 15.75 & \\
\hline & 5 & 40.74 & \\
\hline & 7 & 57.18 & \\
\hline & 9 & 77.98 & \\
\hline
\end{tabular}

ekstrak hidrolisat, dapat disebabkan oleh penggunaan panas tinggi $\left(121^{\circ} \mathrm{C}\right)$ pada proses sterilisasi sebelum ekstraksi. Kestabilan senyawa selain ulvan yang bersifat antioksidan, contohnya klorofil maupun senyawa pigemen lainnya, dapat terdegradasi akibat pemanasan tersebut (Berezin et al., 2017).

\section{Aktivitas antibakteri}

Uji aktivitas antibakteri menunjukkan konsentrasi ekstrak yang sebanding dengan persentase daya hambat bakteri (Tabel 2). Aktivitas antibakteri sampel ekstrak hidrolisat hasil penelitian lebih tinggi daripada Kavitha et al. (2017) yang tidak menggunakan proses hidrolisis. Hasil penelitian juga menunjukkan bahwa sampel ekstrak hidrolisat memiliki aktivitas antibakteri yang lebih tinggi terhadap bakteri gram positif ( $S$. Aureus) daripada gram negatif ( $P$. aeroginosa).

Namun daya hambat bakteri dari ekstrak hidrolisat adalah rendah, jika dibandingkan dengan kontrol natrium benzoat. Oleh karena itu, potensi ekstrak sebagai agen antibakteri adalah rendah. Penelitian yang dilakukan oleh Liswandari et al. (2018) melaporkan ekstrak alga hijau (Ulva sp.) menghambat bakteri Escherichia coli (diameter hambat 8,47 mm) dan Staphylococcus aureus (diameter hambat 8,90 $\mathrm{mm}$ ). Riset Tran et al. (2017) menemukan diameter daya antibakteri ekstrak air Ulva recticulata terhadap
E. coli, P. aeruginosa dan E. cloace maksimal sebesar $20,00 \pm 1,00 \mathrm{~mm}$. Bahkan Kavitha et al. (2017) tidak menemukan adanya daya antibakteri pada ekstrak air U. lactuca. Hasil ini menunjukkan potensi antibakteri yang rendah dari ekstrak ulvan.

\section{Aktivitas antikoagulan}

Hasil pengamatan menunjukkan masa aktivitas koagulasi darah kontrol (tidak diberi perlakuan) yang berkisar pada menit ke-8 hingga 12 (Tabel 3). Sampel darah kontrol yang diambil masih dalam batas waktu pembekuan darah normal, yang diketahui berkisar antara 3-18 menit (Mirdha \& Jena, 2016). Sampel yang ditambah dengan ekstrak hidrolisat tidak mengalami pembekuan darah. Oleh karena itu, ekstrak hidrolisat berpotensi sebagai antikoagulan. Masa pembekuan (koagulasi) darah kontrol dari masing-masing pendonor tampak mengalami perbedaan waktu. Sampel ekstrak hidrolisat kapang EN dan bakteri BL memiliki rata-rata tingkat kekentalan yang sama. Namun, jika dibandingkan dengan sampel yang telah ditambahkan EDTA, sampel ekstrak memiliki rata-rata tingkat kekentalan yang lebih tinggi (Tabel 4). Kammoun et al. (2017) menyatakan bahwa EDTA memiliki kemampuan pengkelat yang lebih tinggi daripada polisakarida ekstrak U. lactuca. Salah satu faktor pembekuan darah adalah keberadaan kalsium 
Tabel 2. Aktivitas antibakteri ekstrak hidrolisis U. lactuca dengan kapang endofit dari tanaman Enhalus (EN) dan isolat bakteri (BL) dari rumput laut $E$. cottonii

Table 2. Antibacterial activities of extract from $\underline{U}$ lactuca hydrolysed by microbial endophytic fungi from Enhalus plants (EN) and marine bacteria isolated from E. cottonii (BL)

\begin{tabular}{lccc}
\hline \multicolumn{1}{c}{ Sampel/Sample } & $\begin{array}{c}\text { Konsenterasi/ } \\
\text { Concentration } \mathbf{( m g / m L )}\end{array}$ & S. aureus & P. aeroginosa \\
\hline Ekstrak hidrolisat U. lactuca & 1 & $21 \%$ & $8 \%$ \\
dengan kapang EN/Hydrolysate & 2 & $25 \%$ & $10 \%$ \\
extract of U. lactuca with EN & 3 & $26 \%$ & $13 \%$ \\
fungi & 4 & $31 \%$ & $18 \%$ \\
& 5 & $35 \%$ & $22 \%$ \\
\hline \multirow{2}{*}{ Ekstrak hidrolisat U. lactuca } & 1 & $17 \%$ & $7 \%$ \\
dengan bakteri BL/Hydrolysate & 2 & $21 \%$ & $8 \%$ \\
extract of U. lactuca with BL & 3 & $28 \%$ & $13 \%$ \\
bacteria & 4 & $33 \%$ & $13 \%$ \\
& 5 & $36 \%$ & $14 \%$ \\
\hline Natrium benzoat/Sodium benzoate & 5 & $96 \%$ & $82 \%$ \\
\hline
\end{tabular}

Tabel 3. Waktu koagulasi darah (menit) ekstrak hidrolisis U. lactuca dengan kapang endofit dari tanaman Enhalus (EN) dan isolat bakteri (BL) dari rumput laut $E$. cottonii

Table 3. Blood clotting time (minutes) of extract from U. lactuca hydrolysed by microbial endophytic fungi from Enhalus plants $(E N)$ and marine bacteria isolated from E. cottonii (BL)

\begin{tabular}{|c|c|c|c|c|}
\hline Sampel darah/Blood sample & A & B & AB & 0 \\
\hline Darah kontrol/Blood control & 12 & 9 & 8 & 11 \\
\hline Akuades/Aquadest & 11 & 7 & 6 & 9 \\
\hline $\begin{array}{l}\text { Ekstrak hidrolisat U. lactuca dengan kapang } \\
\text { EN/Hydrolysate extract of } \underline{\underline{U} .} \text { lactuca with EN fungi }\end{array}$ & TK & TK & TK & TK \\
\hline $\begin{array}{l}\text { Ekstrak hidrolisat } U \text {. lactuca dengan bakteri } \\
\mathrm{BL} / \text { Hydrolysate extract of } \underline{U} \text {. lactuca with } B L \text { bacteria }\end{array}$ & TK & TK & TK & TK \\
\hline EDTA & TK & TK & TK & TK \\
\hline
\end{tabular}

Keterangan/Note: $\mathrm{TK}=$ tidak terjadi koagulasi darah pada sampel $/ T K=$ uncoagulated blood

Tabel 4. Rata-rata tingkat kekentalan sampel darah yang ditambahkan ekstrak hidrolisis U. lactuca dengan kapang endofit dari tanaman Enhalus (EN) dan isolat bakteri (BL) dari rumput laut $E$. cottonii

Table 4. Average level of blood samples coagulation with the addition of extract from U. lactuca hydrolysed by microbial endophytic fungi from Enhalus plants (EN) and marine bacteria isolated from E. cottonii (BL)

\begin{tabular}{|c|c|c|c|c|c|c|c|c|}
\hline \multirow{2}{*}{ Sampel/Sample } & \multicolumn{8}{|c|}{ Waktu (menit)/Time (minutes) } \\
\hline & 5 & 10 & 15 & 30 & 45 & 60 & 90 & 120 \\
\hline Darah kontrol/Blood control & 1 & 2 & 4 & 4 & 4 & 4 & 4 & 4 \\
\hline Akuades/Aquadest & 1 & 3.5 & 4 & 4 & 4 & 4 & 4 & 4 \\
\hline Ekstrak hidrolisat $U$. lactuca dengan kapang & & & & & & & & \\
\hline $\begin{array}{l}\text { EN/Hydrolysate extract of } \underline{U} \text {. lactuca with EN } \\
\text { fungi }\end{array}$ & 1 & 1 & 1 & 1 & 1.5 & 2 & 2 & 3 \\
\hline Ekstrak hidrolisat $U$. lactuca dengan bakteri & & & & & & & & \\
\hline $\begin{array}{l}\text { BL/Hydrolysate extract of } \underline{U} \text { lactuca with } B L \\
\text { bacteria }\end{array}$ & 1 & 1 & 1 & 1 & 1.5 & 2 & 2 & 3 \\
\hline EDTA & 1 & 1 & 1 & 1 & 1 & 2 & 2 & 2 \\
\hline
\end{tabular}

Keterangan/Note: 1 =cair; $2=$ kental; 3 = sangat kental; $4=$ beku/1=liquid; $2=$ viscous; $3=$ very viscous; $4=$ clotting 
dalam plasma darah. EDTA merupakan antikoagulan yang dapat mengikat kalsium sehingga tidak dapat berperan dalam proses pembekuan.

Ulvan telah dilaporkan memiliki berat molekul hingga $2000 \mathrm{kDa}$, dengan rata-rata berat molekul 5 kDa (Li, Wen, Sun, Zhao, \& Chen, 2018; Qi et al., 2005). Aktivitas antikoagulan ekstrak U. lactuca (ulvan larut air dengan berat molekul rendah) dapat menunda waktu pembekuan darah, yaitu lebih dari 200 detik untuk WPTT (waktu trompolastin parsial teraktivasi) dan 120 detik untuk WT (waktu trombin), sementara WPT (waktu protrombin) tidak dapat ditunda ( $\mathrm{Li}$ et al., 2018). Proses koagulasi memiliki jalur pembekuan fibrin secara intrinsik dan ekstrinsik, WPTT berkaitan dengan jalur intrinsik dan WPT berkaitan dengan jalur ekstrinsik. WT berhubungan dengan aktivitas trombin atau polimerisasi fibrin. Kurangnya aktivitas perpanjangan WPT menunjukkan tidak ada penghambatan koagulasi jalur ekstrinsik. Ulvan diduga bertindak pada jalur koagulasi intrinsik, yaitu melalui efek pada aktivitas trombin atau konversi fibrinogen menjadi fibrin. Jika dibandingkan dengan heparin, ulvan memiliki aktivitas antikoagulan ringan yang mirip dengan heparin bermolekul rendah (LMWH). LMWH berasal dari proses depolimerisasi polidispersi heparin yang memiliki berat molekul di bawah $6 \mathrm{kDa}$. LMWH telah digunakan secara luas sebagai antikoagulan dan memiliki setengah aktivitas heparin dan risiko perdarahan lebih sedikit. Ulvan dapat diteliti lebih lanjut sebagai alternatif untuk LMWH.

\section{KESIMPULAN}

Metode hidrolisis cair secara mikrobiologis dengan kapang endofit dari tanaman Enhalus dan isolat bakteri dari rumput laut $E$. cottonii memberikan rendemen ekstrak ulvan dari $U$. lactuca yang lebih tinggi dibandingkan dengan metode hidrolisis kimawi. Selain itu, durasi waktu hidrolisis mikrobiologi yang optimal adalah 3 hari. Hasil ekstrak dari hidrolisis ini memiliki karakteristik $100 \%$ larut air, tidak berpotensi sebagai antioksidan dan antibakteri, namun memiliki aktivitas antikoagulan.

\section{UCAPAN TERIMA KASIH}

Ucapan terima kasih kami sampaikan untuk CV OCEAN FRESH yang telah menyediakan sebagian dana pada penelitian ini.

\section{DAFTAR PUSTAKA}

Adrien, A., Bonnet, A., Dufour, D., Baudouin, S., Maugard, T., \& Bridiau, N. (2017). Pilot production of ulvans from Ulva sp. and their effects on hyaluronan and collagen production in cultured dermal fibroblasts.
Carbohydrate Polymers, 157, 1306-1314. doi: 10.1016/j.carbpol.2016.11.014

Ahmed, O. M., \& Ahmed, R. R. (2014). Anti-proliferative and apoptotic efficacies of ulvan polysaccharides against different types of carcinoma cells in vitro and in vivo. Journal of Cancer Science and Therapy, 6(6), 202-208.doi: 10.4172/1948-5956.1000272

Ambarsari, N. D., Rushanti, I. R. P. A., Setyaji, A., Ningsih, T. A., Nurhana, N., Subekhi, I., \& Dewi, E. (2018). The influenced of Lactobacillus plantarum starter addition and the length time of fermentation process on the activity of seaweed antioxidant Ulva lactuca from Krakal Beach, Yogyakarta. IOP Conf. Series: Earth and Environmental Science, 116 (2018).

Andhikawati, A., Oktavia, Y., Ibrahim, B., \& Tarman, K. (2014). Isolasi dan penapisan kapang laut endofit penghasil selulase. Jurnal IImu dan Teknologi Kelautan Tropis, 6(1), 219-228.

Arbi, B., Maruf, W. F., \& Romadhon. (2016). The activity of bioactive compounds from Sea Lettuce (Ulva lactuca) as antioxidant in fish oil. Indonesian Journal of Fisheries Science and Technology, 12(1), 12-18

Armiyanti, L., Paransa, D. S., \& Gerung, G. S. (2013). Uji aktivitas antikoagulan pada sel darah manusia dari ekstrak alga coklat Turbinaria ornata. Jurnal Pesisir dan Laut Tropis, 1(2), 21-27. doi: 10.35800/ jplt.1.2.2013.2094

Berezin, D. B., Makarov, V. V., Guseinov, S. S., Romanenko, Y. V., Khudyaeva, I. S., Startseva, O. M.,...Kustov, A. V. (2017). Thermal stability of chlorophyll a derivatives containing hydrophilic groups. Russian Journal of General Chemistry, 87(7), 1557-1561. doi: 10.1134/ S1070363217070192

Chiellini, F., \& Morelli, A. (2011). Ulvan: A Versatile platform of biomaterials from renewable resources. Biomaterials - Physics and Chemistry. doi: 10.5772/24901

Coste, O., Malta, E. jan, López, J. C., \& Fernández-Díaz, C. (2015). Production of sulfated oligosaccharides from the seaweed Ulva sp. using a new ulvandegrading enzymatic bacterial crude extract. Algal Research, 10, 224-231. doi: 10.1016/ j.algal.2015.05.014

Dominguez, H., \& Loret, E. P. (2019). Ulva lactuca, A Source of troubles and potential riches herminia. Marine Biotechnology, 357(17), 1-20.

Fajardo, S., García-Galvan, R. F., Barranco, V., Galvan, J. C., \& Batlle, S. F. (2016). Therapeutic potential of seaweed bioactive compounds. Seaweed Biomaterials, 2, 8-25. doi: 10.5772/57353

Imran, M. D., Poduval, P. B., \& Ghadi, S. I. (2016). Bacterial degradation of algal polysaccharides in marine ecosystem. Marine Pollution and Microbial Remediation, 189-203. doi: 10.1007/978-981-101044-6_12

Kammoun, I., Bkhairia, I., Ben Abdallah, F., Jaballi, I., Ktari, N., Boudawara, O.,....Ben Amara, I. (2017). Potential protective effects of polysaccharide extracted from Ulva lactuca against male reprotoxicity induced by thiacloprid. Archives of Physiology and Biochemistry, 123(5), 334-343.doi: 10.1080/ 13813455.2017.1347686 
Kavitha, S., Subbulakshmi, P., Rajesh Banu, J., Gobi, M., \& Tae Yeom, I. (2017). Enhancement of biogas production from microalgal biomass through cellulolytic bacterial pretreatment. Bioresource Technology, 233, 34-43. doi: 10.1016/ j.biortech.2017.02.081

Khairina, R., Fitrial, Y., Satrio, H., \& Rahmi, N. (2016). Physical, chemical, and microbiological properties of "ronto" a traditional fermented shrimp from South Borneo, Indonesia. Aquatic Procedia, 7, 214-220. doi: 10.1016/j.aqpro.2016.07.029

Kuhad, R. C., Gupta, R., \& Singh, A. (2011). Microbial cellulases and their industrial applications. Enzyme Research. doi: 10.4061/2011/280696

Lahaye, M., \& Robic, A. (2007). Structure and function properties of Ulvan, a polysaccharide from green seaweeds. Biomacromolecules, 8(6), 1765-1774. doi: $10.1021 / \mathrm{bm} 061185 \mathrm{q}$

Lauzon, D. Q., \& Serrano, A. E. J. (2015). Ulvan extract from Enteromorpha intestinalis enhances immune responses in Litopenaeus vannamei and Penaeus monodon juveniles. ABAH Bioflux, 7(1), 1-10.

Lee, N. Y., Yunus, M. A. C., Idham, Z., Ruslan, M. S. H., Aziz, A. H. A., \& Irwansyah, N. (2016). Extraction and identification of bioactive compounds from agarwood leaves. Materials Science and Engineering, 162(1), 12-28. doi: 10.1088/1757-899X/162/1/012028

Li, P., Wen, S., Sun, K., Zhao, Y., \& Chen, Y. (2018). Structure and bioactivity screening of a low molecular weight ulvan from the green alga Ulothrix flacca. Marine Drugs, 16(8), 21-34. doi: 10.3390/md16080281

Liswandari, M. S., Lantang, D., \& Dirgantara, S. (2018). Uji aktivitas antibakteri alga hijau (Ulva sp.) dari pantai Sorido Biak terhadap bakteri Escherichia coli dan Staphylococcus aureus. Pharmacy Medical Journal, 1(1), 9-15.

Mirdha, M., \& Jena, S. (2016). Distribution of blood group and its relation to bleeding time and clotting time. International Journal of Medical Science and Public Health, 5(12), 2566-2570. https://doi.org/10.5455/ ijmsph.2016.13052016526

Novianti, M., Aini, Q., Putri, I. \& Kusumaningsih, T. (2015). Uji aktivitas antibakteri dari senyawa hasil ekstraksi daun nyamplung (Calophyllum inophyllum Linn.). Alchemy Jurnal Penelitian Kimia, 11(2), 200-210.

Postma, P. R., Cerezo-Chinarro, O., Akkerman, R. J., Olivieri, G., Wijffels, R. H., Brandenburg, W. A., \& Eppink, M. H. M. (2018). Biorefinery of the macroalgae Ulva lactuca: extraction of proteins and carbohydrates by mild disintegration. Journal of Applied Phycology, 30(2), 1281-1293. doi: 10.1007/s10811-017-1319-8

Pudiastuti L. \& Pratiwi T. (2013). Pembuatan dekstrin dari tepung tapioka secara enzimatik dengan pemanas microwave. Jurnal Teknologi Kimia dan Industri UNDIP, 2(2),169-176.

Qi, H., \& Sheng, J. (2015). The antihyperlipidemic mechanism of high sulfate content ulvan in rats. Marine Drugs, 13(6), 3407-3421. doi: 10.3390/ md13063407
Qi H., Zhao T., Zhang Q., LiZ., Zhao Z., Xing R. (2005). Antioxidant activity of different molecular weight sulfated polysaccharides from Ulva pertusa Kjellm (Chlorophyta). Journal of Applied Phycology, 17(6), 527-534.

Ramu Ganesan, A., Shanmugam, M., \& Bhat, R. (2018). Producing novel edible films from semi refined carrageenan (SRC) and ulvan polysaccharides for potential food applications. International Journal of Biological Macromolecules, 112, 1164-1170. doi: 10.1016/j.ijbiomac.2018.02.089

Rizk, M. Z., Aly, H. F., Matloub, A. A., \& Fouad, G. I. (2016). The anti-hypercholesterolemic effect of ulvan polysaccharide extracted from the green alga Ulva fasciata on aged hypercholesterolemic rats. Asian Journal of Pharmaceutical and Clinical Research, 9(3), 165-176.

Robic, A., Rondeau-Mouro, C., Sassi, J. F., Lerat, Y., \& Lahaye M. (2009). Structure and interactions of ulvan in the cell wall of the marine green algae UIva rotundata (Ulvales, Chlorophyceae). Carbohydrate Polymer. 77, 206-216.

Rybak, A. S. (2018). Species of Ulva (Ulvaphyceae, Chlorophyta) as indicators of salinity. Ecological Indicators, 85, 253-261. doi: 10.1016/ j.ecolind.2017.10.061

Sandria, N., Uju, U., \& Suptijah, P. (2017). The Depolymerization of Kappa Carrageenan Using Peracetic Acid. Jurnal Pengolahan Hasil Perikanan Indonesia, 20(3), 524-535. doi: 10.17844/ jphpi.v20i3.19809

Santhi, S. S., Bhagat, A. K., Saranya, S., Govindarajan, G., \& Jabekumar, S. R. D. (2014). Seaweed (Eucheuma cottonii) associated microorganisms, a versatile enzyme source for the lignocellulosic biomass processing. International Biodeterioration \& Biodegradation, 96, 144-151. doi: 10.1016/ j.ibiod.2014.08.007

Sinurat, E., \& Maulida, N. N. (2018). Pengaruh hidrolisis fukoidan terhadap aktivitasnya sebagai antioksidan. Jurnal Pascapanen dan Bioteknologi Kelautan dan Perikanan, 13(2), 123-130. doi: 10.15578/ jpbkp.v13i2.522

Synytsya, A., Choi, D. J., Pohl, R., Na, Y. S., Capek, P., Lattová, E., .... Park, Y. II. (2015). Structural features and anti-coagulant activity of the sulphated polysaccharide SPS-CF from a green alga Capsosiphon fulvescens. Marine Biotechnology, 17(6), 718-735. doi: 10.1007/s10126-015-9643$\mathrm{y}$

Thanh, T. T. T., Quach, T. M. T., Nguyen, T. N., Vu Luong, D., Bui, M. L., \& Tran, T. T. Van. (2016). Structure and cytotoxic activity of ulvan extracted from green seaweed Ulva lactuca. International Journal of Biological Macromolecules, 93, 695-702. doi: 10.1016/j.ijbiomac.2016.09.040

Tran, T. T. V., Truong, H. B., Tran, N. H. V., Quach, T. M. T., Nguyen, T. N., Bui, M. L., ... Thanh, T. T. T. (2018). Structure, conformation in aqueous solution and antimicrobial activity of ulvan extracted from green 
JPB Kelautan dan Perikanan Vol. 15 No. 2 Tahun 2020: 123-132

seaweed Ulva reticulata. Natural Product Research, 32(19), 2291-2296. doi: 10.1080/ 14786419.2017 .1408098

Yaich, H., Amira, A. B., Abbes, F., Bouaziz, M., Besbes, S., Richel, A., ... Garna, H. (2017). Effect of extraction procedures on structural, thermal and antioxidant properties of ulvan from Ulva lactuca collected in Monastir coast. International Journal of Biological Macromolecules, 105, 1430-1439. doi: 10.1016/ j.ijbiomac.2017.07.141 